\title{
The relation between 1 Thessalonians and 2 Thes- salonians and the inauthenticity of 2 Thessalonians
}

Eduard Verhoef

Hollandsche Rading

The Netherlands

\begin{abstract}
The relation between 1 Thessalonians and 2 Thessalonians is a disputed question. Many scholars argue that 2 Thessalonians is pseudepigraphic, written one or more decades after 1 Thessalonians. Others defend the authenticity of 2 Thessalonians. Wanamaker argues in his recent commentary that 2 Thessalonians was written before 1 Thessalonians. In this way the problems raised by the complicated relation between the two letters would be solved. Wanamaker argues that Timothy on his visit to Thessalonica (1 Thes 3:1-5) brought the letter we call 2 Thessalonians. Lecompte argues that Silas wrote 1 Thessalonians and that Paul himself is the author of 2 Thessalonians, so he could correct the misunderstandings caused by Silas's writing. Or perhaps Silas did not exactly write what Paul had agreed with his co-workers. I will argue in this article that the arguments used by Wanamaker and Lecompte are invalid for grammatical reasons. The great resemblance between 1 Thessalonians and 2 Thessalonians in spite of these different opinions, is best explained if we see 2 Thessalonians as a pseudepigraphic epistle.
\end{abstract}

The epistles which are known under the names 1 Thessalonians and 2 Thessalonians have in their prescripts three senders: Paul, Silas and Timothy. In these prescripts there is no distinction between the three senders. This means that Paul as well as Silas and Timothy are proposed as the real senders of these epistles. As a consequence, in these epistles the plural of the first person is used nearly without exception ${ }^{2}$. We can regard this co-authorship in the following way: we find here the result of the conversations Paul held with Silas and Timothy (Verhoef 1995a:55). Though these are cosenders, Paul's role was the most important. In my opinion 1 Thessalonians is written by Paul himself as is the case with the other Pauline epistles which have an other name 
besides Paul's in the prescript ( 1 Cor; 2 Cor; Phlp; [Col] and Phlm). Language, style, social and theological contents confirm that this letter has been written by one author, Paul (Verhoef 1994:70; 1996a:420-432). About 2 Thessalonians we will speak broadly below.

It seems to me that the right method is to read the information about the senders with 'critical sympathy3'. This means that as long as there is no reason to doubt the information given in the prescripts, the senders mentioned really are the writers of these letters, though we mst reckon with the fact that Paul had a bigger part in conceiving these letters than his co-senders.

With regard to 1 Thessalonians, most scholars think that Paul was the author, although there are a few exceptions. The so-called Dutch Radicals rejected at the end of the last century the authenticity of all the 'Pauline' epistles, an opinion which has recently been breathed new life into by Hermann Detering (1992) ${ }^{4}$. Another opinion, defended by Lecompte (1984), is that not Paul, but Silas, was the author of 1 Thessalonians (see below). I would like to maintain the authorship of Paul. I see no reason to doubt the information in the prescript, although it is clear that the three senders were not equal authors. A second argument that confirms the authenticity of this letter is the chapter about the coming of the Lord. The expectation that the coming of the Lord would be soon suggests that this letter is a very old one, written not later than the middle of the first century. We do not know of other persons of this era besides Paul who could have written such a letter.

There are many difficulties with regard to 2 Thessalonians. Paul and Silas and Timothy are mentioned as the senders in the prescript in exactly the same way as in 1 Thessalonians. But the authenticity of this epistle has been questioned since the end of the 18 th century (see Bornemann 1894:498). Since then the scholars have been divided in their opinion: is 2 Thessalonians an authentic epistle written by Paul or do we have here a pseudepigraphic letter? In my opinion the most important reason to doubt the authenticity of this epistle is that in spite of the striking similarities with 1 Thessalonians, the eschatology is spoken about differently, especially in chapter 2 . In 2 Thessalonians 2 the author argues that there is still a long way to go before the coming of the Lord (2 Th 2:3-12), whereas in 1 Thessalonians 4-5 Paul's statements imply that the Lord will arrive very soon (see 1 Th 4:15, 17; 5:10; see Verhoef 1995b:10-11).

I need not repeat here the arguments which have been used for the last two centuries $^{5}$. For this paper I will restrict myself to the arguments used by Lecompte $(1984,1985)$ and those used by Wanamaker $(1990)$ to save the authenticity of 2 Thessalonians ${ }^{6}$.

First I would like to discuss Wanamaker's reasoning in his recent commentary on the epistles to the Thessalonians. Wanamaker speaks exhaustively about Trilling's arguments against the authenticity of 2 Thessalonians (see Trilling 1972). Wanamaker 
(1990:28) says that Trilling's book does not offer 'a compelling argument' against the authenticity of 2 Thessalonians. But even if we accept the authenticity of 2 Thessalonians 'the traditional understanding of 2 Thessalonians as Paul's second epistle to the church at Thessalonica' is not 'completely satisfactory' to him (Wanamaker 1990:28). Wanamaker (1990:37-45) pays much attention to the problem of the sequence of these letters. It must be clear that the biblical order is not necessarily the chronological one. The order of the Pauline epistles in the Bible seems to be an order on the basis of length (Bruce 1982:XLI). So it is the content of the letters which must make clear which letter was the first.

There is no need to repeat here the arguments used by Manson (1952/53:428-447) defending the priority of 2 Thessalonians and the counter-arguments by Jewett (1986:24-30), Best (1977:42-45) and others. But it is interesting to read the way Wanamaker is reasoning in his discussion with Jewett.

First of all he studies the statements in 2 Thessalonians 2:27, 2 Thessalonians 2:15 and 2 Thessalonians 3:17. According to most authors it is suggested in these texts that another letter, maybe a forgery, already existed. Perhaps 2 Thessalonians 2:15 is the most important text. The use of $\dot{\varepsilon} \delta \delta \alpha \dot{\alpha} \chi \eta \eta \varepsilon$, you were taught, usually appoints to an

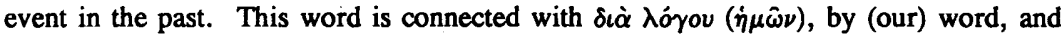
with $\delta i \dot{\varepsilon} \pi\llcorner\sigma \tau o \lambda \hat{\eta} \varsigma \dot{\eta} \mu \hat{\omega} \nu$, by a letter of ours. In this sentence it is suggested that the author of these words spoke to the Thessalonians and that he wrote a letter before the present one. Wanamaker (1990:41) proposes the possibility that only with regard to $\delta i$ $\dot{\varepsilon} \pi\llcorner\sigma \tau o \lambda \hat{\eta} \varsigma$ this aorist must be interpreted as an epistolary aorist, so it would allude to the present epistle and with regard to $\delta i \dot{\alpha} \lambda$ ó $\gamma o v$ the verb would refer to an event in the past. However, it would be very strange to connect the 'teaching by our word' with the past and to connect the 'teaching by an epistle of ours' with this epistle. Of course, Paul did use an epistolary aorist several times (e $\mathrm{g}$ in Phlm 19: ह̌ $\gamma \rho \alpha \psi \alpha$, I wrote, referring to what Paul writes at that very moment), but it is difficult to interpret this verb in different ways for the constructions mentioned above.

Another argument for Wanamaker is that 'in epistolary rhetoric it is normal to refer back to the preceding stages of a relationship' (Wanamaker 1990:43). We would expect a reference to another epistle if such a letter existed. According to Wanamaker in 1 Thessalonians 3:1-5 we can find a reference to Timothy's visit to the Thessalonians, the visit during which he delivered 2 Thessalonians. Wanamaker (1990:44) concludes from 1 Thessalonians 3:3 and from 2 Thessalonians 2:1-2 that 'both 2 Thessalonians and Timothy's visit had the same purpose'. To me this seems very speculative. We do not know that Timothy delivered an epistle by Paul to the Thessalonians. Paul does not say anything about that. And the purpose of Timothy's visit to the Thessalonians seems to be very different from the contents of 2 Thessalonians. In my view the purpose of Timothy's visit was to support and encourage the Thessalonians and to 
get information about their situation for Paul (1 Th 3:2, 3, 5), whereas the purpose of 2 Thessalonians is to take away the trouble which arose by the statement that the 'Day of the Lord is coming now' (2 Th 2:2; see Lietaert Peerbolte 1995:72-75). So, it seems very improbable that Timothy's visit and 2 Thessalonians had the same purpose. And there is no reason to suppose that it was at Timothy's visit, mentioned in 1 Thessalonians 3:1, 5 and 6 , that 2 Thessalonians was delivered to the Thessalonians and that in consequence 2 Thessalonians was written earlier than 1 Thessalonians. Jewett (1986:27-28) argues correctly that the lack of any reference to another epistle in 1 Thessalonians suggests that there is no former letter to the Thessalonians.

On the contrary in my opinion there are several arguments in favour of the priority of 1 Thessalonians. This epistle suggests that it was written shortly after the first time Paul visited Thessalonica. In 1 Thessalonians 1:5, 6, 9, and in 2:1-2 Paul speaks about his recent visit to the Thessalonians, about his preaching of the gospel in this city after the sudden and compelled flight out of Philippi (1 Th 2:2), about their conversion (1 Th 1:9) and about his big worries for this young community (1 Th 3:1-5). All these texts give the impression that this community was founded very recently and that Paul wants to give them more support after his departure and that he wants to be informed of their situation. In my opinion there is no argument against this statement. Therefore I would like to conclude that 1 Thessalonians is written before 2 Thessalonians and that with regard to the authenticity of 2 Thessalonians we must as before reckon with the arguments given by Trilling and others.

Lecompte (1984:137-144) reasons in a very different way. He explains the great resemblance between the two epistles on the one hand and the different opinions in these epistles about eschatology on the other hand by his statement that Silas would be the author of the first epistle and that Paul would have written the second epistle.

He stresses the fact that in 1 Thessalonians we find the first person plural so often (Lecompte 1984:141-142). He argues that all three senders of this epistle have an equal role in making decisions ${ }^{8}$ and all three conceived this epistle 9 .

In 1 Thessalonians 2:18 we read 'I, Paul', in 1 Thessalonians 3:1 Timothy is mentioned and in 1 Thessalonians 3:5 we read $\kappa \dot{\alpha} \gamma \dot{\omega}$ (literally: and I). In 1 Thessalonians 2:18 we find that all three senders intend to come to Thessalonica. Paul stresses that he himself tried to come to the Thessalonians more than once. 1 Thessalonians 3:1 speaks of the common decision to send Timothy and in 1 Thessalonians 3:5, so argues Lecompte, the person hidden in the $\kappa \dot{\alpha} \gamma \dot{\omega}$ must be Silas, the third sender. He translates $\kappa \dot{\alpha} \gamma \dot{\omega}$ with 'I too', I besides Paul and Timothy. Lecompte concludes then that the nameless ' $\mathrm{I}$ ' in 1 Thessalonians 3:5 is identified as Silas. In the same way the nameless ' $I$ ' is identified for the next part of this letter ${ }^{10}$. He states that there is no need to mention Silas's name here because it is clear that Silas is meant ${ }^{11}$. 
I submit that this is not clear at all. The meaning of $\kappa \dot{\alpha} \gamma \dot{\omega}$ can be 'I too'. See for example 1 Corinthians 15:8 ( $\kappa \dot{\alpha} \mu o i) ; 2$ Corinthians 11:22. In 1 Corinthians 16:10 Paul says about Timothy that he does the work of the Lord $\dot{\omega} \varsigma \kappa \dot{\alpha} \gamma \dot{\omega}$, as I too did. In other texts $\kappa \dot{\alpha} \gamma \dot{\omega}$ has the meaning 'and I'; see for example Philippians 2:28 and so on. Another possibility is that the conjunction (or adverb?) $\alpha$ $\alpha$ i only stresses the next word; see for example Romans 3:712.

What then must be the meaning of $\alpha \alpha i$ in 1 Thessalonians 3:5? Lünemann also argued in 1850 that $\kappa \dot{\alpha} \gamma \dot{\omega}$ would mean 'I too' (Lünemann 1850:86-87). His interpretation however, is that the ' $I$ ' is Paul and that 'too' refers to Paul's friends in Athens. Though Lünemann is nearer to the truth than Lecompte with his interpretation that Paul is meant with ' $\mathrm{I}$ ', his interpretation of $\alpha \alpha i$ is wrong in my opinion. Others propose that the meaning of $\alpha \alpha i$ in this verse is to stress either the pronoun (Blass et al 1984,

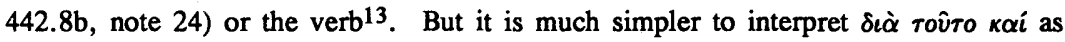
'therefore then'14. The article $\kappa \alpha i$ is then the so-called $\kappa \alpha i$-consecutivum (Blass et al 1984, number 442.2). For this $\alpha \alpha i$ we can find many examples in the literature. As Josephus in his Antiquities tells about the flood and about the constructing of the ark he

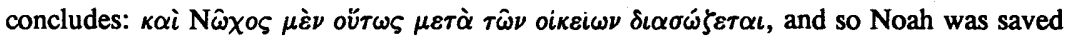
with his family (Niese 1887:18).

Another question is: why would Silas have concealed his own name, if he was the author who actually wrote this epistle? In 1 Thessalonians 2:18 the ' $\mathrm{I}$ ' is connected with Paul's name. It is evident that the $\kappa \dot{\alpha} \gamma \dot{\omega}$ in 1 Thessalonians 3:5 refers to the same person as the $\dot{\varepsilon} \gamma \omega$ in 1 Thessalonians $2: 18$, unless there would be a strong reason to identify the ' $I$ ' of 1 Thessalonians 3:5 as another person. I see no reason to do this.

Another difficulty in 1 Thessalonians 3:5 for Lecompte's interpretation is the verb $\varepsilon \check{\pi} \pi \mu \psi \alpha$, I sent. We already saw that he stresses the fact that the decisions were joint decisions of the three senders. But what about the form 'I sent'? Are we really to believe that it was Silas who sent Timothy? And was it Silas who wanted to know about their belief and was it Silas who was anxious that the tempter had tempted them and that their labour had been idle? And what about the relation between this 'I sent' and 'we sent' in 1 Thessalonians 3:1? In line with 1 Thessalonians 2:18 and with Paul's leadership in the preaching of the gospel we must assume that it was Paul himself who conceived and dictated the epistle, that it was he who sent Timothy and that the plural forms in this letter refer to co-operation with Silas and Timothy (see Verhoef 1995a:55). Sometimes the singular is used even when there are more senders in the other epistles as well (Verhoef 1995a:51). Elsewhere I argued that the irregular use of plural and singular in the Pauline epistles can be explained by the fact that it was Paul himself who was the author and that the role of the co-senders was rather small (Verhoef 1995a:57; 1996b:417-425). The function of $\kappa \dot{\alpha} \gamma \dot{\omega}$ in 1 Thessalonians $3: 5$ is 
totally in line with the use of the singular and plural and with the use of the first person pronouns in the other epistles. It is rather strange if this 1 Thessalonians $\alpha \dot{\alpha} \gamma \dot{\omega}$ must suddenly refer to Silas.

After his conclusion with regard to 1 Thessalonians 3:5 Lecompte discusses the question who dictated or really wrote the letter. He argues in the following way. In 1 Thessalonians 5:25-27 we read two imperatives. The orders can be given only by the three senders. So these imperatives must have originated from Paul, Silas and Timothy. After these orders we find a call in the singular (èvopki $\zeta \omega$, I adjure) to read this epistle aloud to all the brothers. This care for the letter is caused by the fact that the 'I' is the one who materially dictated or wrote the letter. The singular has been used because the person who formulated this sentence is the one who materially dictated or wrote this letter. The subject of this verb must be the same 'I' already identified for 1 Thessalonians 3:5 (Lecompte 1984:142). As we have seen, the ' $I$ ' in 1 Thessalonians 3:5 is not Silas, but Paul who worries about the Thessalonians and who sends Timothy. And it is not Silas who asks the community in Thessalonica to read aloud this letter for all the brothers, but again it is Paul who urgently appeals (he uses

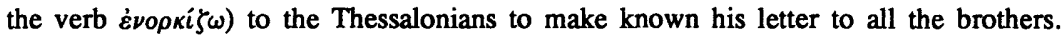
Therefore, in my opinion, 1 Thessalonians is an epistle conceived and probably dictated by Paul. Silas and Timothy were involved in its conception.

In his commentary on 2 Thessalonians Lecompte argues that perhaps the first epistle caused misunderstandings or perhaps Silas did not exactly write what the three senders had agreed ${ }^{15}$. Therefore Paul himself writes the second epistle ${ }^{16}$ to amend the shortcomings of the first one ${ }^{17}$. It must be clear now that in my opinion these arguments are not relevant. Not Silas, but Paul wrote the first epistle to the Thessalonians. And if it was the purpose of 2 Thessalonians to correct the misunderstandings caused by Silas' epistle ( $1 \mathrm{Th})$, then Paul would have been much clearer.

We are stil faced with the problem that there is such a great resemblance between 1 Thessalonians and 2 Thessalonians in spite of the different opinions about the eschatology. Of course it is possible that Paul changed his opinion about eschatology some time after he had written 1 Thessalonians. But is seems to me very improbable that he changed his mind about the coming of the Lord and nevertheless used the same sentences to express his new opinion. The great resemblance between 1 Thessalonians and 2 Thessalonians leads most often to the conclusion that 2 Thessalonians is dependent on 1 Thessalonians (Vielhauer 1975:96-97). This dependency in spite of the different opinions is best explained if we assume that 2 Thessalonians is a pseudepigraphic epistle written some decades later than 1 Thessalonians (Lietaert Peerbolte 1995:6468). 


\section{Endnotes}

1 This is a slightly revised version of a paper presented to the 1996 International SBL-meeting in Dublin. I would like to thank Drs J W Arenthals for the critical remarks on the text.

2 The exeptions are 1 Thessalonians 2:18; 3:5; 5:27 and 2 Thessalonians 3:17.

3 I recommend the same approach of 'critical sympathy' with regard to the problem of the unity of these epistles. This problem is beyond the scope of this paper, but in it I will regard 1 Thessalonians as well as 2 Thessalonians as a unity.

4 For a critical discussion of this opinion see Verhoef (1996a:420-432).

5 For the history of this problem see Bornemann (1894:498-537) and Rigaux (1956:124-132).

6 I do not need to speak here about the article of Trudinger (1995). Trudinger tells that he asked his students to read 2 Thessalonians as if for the first time, to note any issues in that letter about which they would like to have further eludication, thereafter to read 1 Thessalonians and to see if any of their questions were addressed there. The conclusion is predictable: some of the questions raised during the reading of 2 Thessalonians were answered by the reading of 1 Thessalonians, and so in his opinion this result supports the priority of 2 Thessalonians.

7 In regard to 2 Thessalonians Wanamaker (1990:40) says: 'we need not assume that a forgery already existed. Paul may have merely thought that one did or simply considered the possiblity'. But one page further he states: 'in light of $2: 2$, which implies that a forgery may have existed [...]' (Wanamaker 1990:41).

8 In this regard Lecompte (1984:140) states: 'De besluitvorming gebeurt in ieder geval door de "wij".

9 'Paulus, Silas en Timotheus [hebben] de brief gekoncipieerd' (Lecompte 1984:141).

10 'Het “ik” is geïdentificeerd en blijft het voor het ganse.corpus' (Lecompte 1984:141).

11 "Het woordje "ook" identificeer deze derde persoon tegenover de reeds genoemde "ik Paulus" en Timotheus. Er hoeft dus geen naam bijgevoegd te worden' (Lecompte 1984:140).

12 For the different meanings of ' $k \alpha i$ see Blass et al (1984:442).

13 'Characteristic, it would seem, of St. Paul is the displacement of a xai which ought logically to cohere closely with the verb: [...] I Thess.III.5 [...] therefore I actuallly sent' (Moule 1963:167).

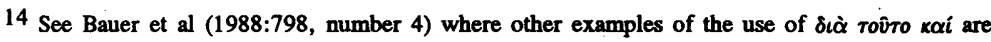
mentioned. 


\footnotetext{
15 'wat onduidelijk geweest of heeft niet precies weergegeven wat de drie hadden afgesproken' (Lecompte 1985:124).

16 Paul 'wil [...] geen misverstanden meer laten ontstaan' (Lecompte 1985:124).

17 'De tweede brief vult [...] de tekorten van de eerste brief aan (Lecompte 1985:124).
}

\section{Works Consulted}

Bauer, K, Aland, K \& Aland, B 1988. Griechisch-deutsches Wöterbuch zu den Schriften des Neuen Testaments und der frühchristlichen Literatur. Berlin: De Gruyter.

Best, E 1977. A commentary on the first and second epistles to the Thessalonians. London: Black. (Black's New Testament Commentaries.)

Bieringer, R (ed) 1996. The Corinthian correspondence. Leuven: Peeters. (BETL 125.)

Blass, F, Debrunner, A \& Rehkopf, F 1984. Grammatik des neutestamentlichen Griechisch. Göttingen: Vandenhoeck.

Bornemann, W 1894. Die Thessalonicherbriefe: Kritisch-exegetischer Kommentar über das Neue Testament. Göttingen: Vanderhoeck.

Bruce, F F 1982. 1 and 2 Thessalonians. Waco: Word Books. (World Biblical Commentary.)

Detering, H 1992. Paulusbriefe ohne Paulus. Frankfurt: Main. (Kontexte, Neue Beiträge zur Historischen und Systematischen Theologie 10.)

Jewett, R 1986. The Thessalonian correspondence: Pauline rhetoric and millenarian piety. Philadelphia: Fortress Press.

Lecompte, C 1984. I Thessalonicenzen, (Verklaring van een bijbelgedeelte). Kampen: Kok.

1985. II Thessalonicenzen (Verklaring van een bijbelgedeelte). Kampen: Kok.

Lietaert Peerbolte, L J 1995. The antecedents of Antichrist. Leiden: Brill.

Lünemann, G 1850. Briefe an die Thessalonicher. Göttingen: Vandenhoeck. (Kritisch exegetischer Kommentar über das Neue Testament.)

Manson, T W 1952/53. St. Paul in Greece: The letters to the Thessalonians. Bulletin of the John Rylands University Library 35, 428-447.

Moule, C D F 1963. An idiom-book of New Testament Greek. Cambridge: Cambridge University Press.

Niese, B 1887. Flavii Iosephi Opera I. Berlin: Weidmann.

Rigaux, B 1956. Les épitres aux Thessaloniciens. Paris: Gabalda. (Études Bibliques.) Trilling, W 1972. Untersuchungen zum zweiten Thessalonicherbrief. Leipzig: St Benno. 
Trudinger, P 1995. The priority of 2 Thessalonians revisited: Some fresh evidence. The Downside Review 113, 31-35.

Verhoef, E 1994. W C van Manen: Een Hollandse Radicale theoloog. Kampen: Kok. 1995a. Numerus, Sekretär und Authentizität der paulinischen Briefe. Protokolle zur Bibel 4/1, 48-58. 1995b. Tessalonicenzen. Kampen: Kok 1996a. Die Holländse radikale Kritik, in Bieringer 1996:427-432. 1996b. The senders of the letters to the Corinthians in connection with the use of ' $\mathrm{I}$ ' and 'We', in Bieringer 1996:417-425.

Vielhauer, P 1975. Geschichte der urchristlichen Literatur. Berlin: De Gruyter.

Wanamaker, C A 1990. The Epistle to the Thessalonians. Grand Rapids: Eerdmans (The New International Greek Testament Commentary.) 